\title{
Optimization of salinity range for rearing glass eel Anguilla bicolor bicolor
}

\section{Optimasi kisaran salinitas pada pendederan glass eel Anguilla bicolor bicolor}

\author{
Ade Yulita Hesti Lukas ${ }^{1 *}$, Daniel Djokosetiyanto², Tatag Budiardi², Agus Oman \\ Sudrajat $^{2}$, Ridwan Affandi ${ }^{3}$ \\ ${ }^{1}$ Department of Aquaculture, Faculty of Fisheries and Marine Science, Nusa Cendana University \\ Jl. Adisucipto Penfui, Kupang - East Nusa Tenggara \\ ${ }^{2}$ Department of Aquaculture, Faculty of Fisheries and Marine Science, Bogor Agricultural University \\ Campus IPB Dramaga Bogor, West Java, Indonesia 16680 \\ ${ }^{3}$ Department of Resources Management Living Aquatic, Faculty of Fisheries and Marine Science \\ Bogor Agricultural University, Kampus IPB Dramaga, West Java, Indonesia 16680 \\ *Email: adeyulitahesti@gmail.com
}

\begin{abstract}
Fasting is one of a method that used for measured growth of fish in a shorter period of time. This study was aimed to determine the optimum range of salinity for improve the survival and growth of glass eel Anguilla bicolor bicolor. It used a completely randomized design (CRD) with four salinity treatments and three replications, namely (A) $0 \mathrm{~g} / \mathrm{L}$, (B) $10 \mathrm{~g} / \mathrm{L}$, (C) $20 \mathrm{~g} / \mathrm{L}$, and (D) $30 \mathrm{~g} / \mathrm{L}$. The fish used were of glass eel A. bicolor bicolor with $0.15-0.23$ $\mathrm{g}$ of weight. The experiment was conducted in an aquarium of $60 \times 30 \times 30 \mathrm{~cm}^{3}$ with a volume of 30 Liters and at a stocking density of $2 \mathrm{~g} / \mathrm{L}$ for 14 days. During the maintenance, glass eels were fasted for have a significantly of biomass decline. Data collection was done at the start and the end of maintenance. Parameters measured included survival (\%) and the rate of decline in absolute biomass $(\mathrm{g})$. Physical and chemical parameters included temperature, dissolved oxygen, and $\mathrm{pH}$ which were measured daily, while ammonia and alkalinity were measured every seven days. Result showed that survival was not significantly different between treatments $(\mathrm{P}>0.05)$, while the rate of decline in absolute biomass was significantly different between treatments $(\mathrm{P}<0.05)$. Treatments of $0 \mathrm{~g} / \mathrm{L}$ salinity was the lowest survival than the others. While treatment of $10 \mathrm{~g} / \mathrm{L}$ salinity was the lowest rate of decline in absolute biomass. According to research, the optimum salinity was $10 \mathrm{~g} / \mathrm{L}$, and after analysis with quadratic regression analysis, the optimum range of salinity were $5.00-13.40 \mathrm{~g} / \mathrm{L}$.
\end{abstract}

Keywords: optimum salinity, survival, growth, glass eel, Anguilla bicolor bicolor

\begin{abstract}
ABSTRAK
Pemuasaan merupakan salah satu metode pengukuran perubahan bobot ikan yang dipelihara dalam waktu singkat. Penelitian ini bertujuan untuk menentukan kisaran salinitas optimum untuk meningkatkan kelangsungan hidup dan pertumbuhan glass eel Anguilla bicolor bicolor. Rancangan penelitian yang digunakan adalah rancangan acak lengkap (RAL), dengan empat perlakuan salinitas dan tiga ulangan, yaitu (A) $0 \mathrm{~g} / \mathrm{L}$, (B) $10 \mathrm{~g} / \mathrm{L}$, (C) $20 \mathrm{~g} / \mathrm{L}$, dan (D) $30 \mathrm{~g} / \mathrm{L}$. Penelitian dilakukan selama 14 hari. Ikan yang digunakan adalah glass eel A. bicolor bicolor dengan bobot 0,15-0,23 g dengan padat tebar $2 \mathrm{~g} / \mathrm{L}$. Pemeliharaan dilakukan di akuarium berukuran $60 \times 30 \times 30 \mathrm{~cm}^{3}$ dengan volume air 30 Liter/akuarium. Selama pemeliharaan glass eel dipuasakan sehingga diperoleh penurunan biomassa yang signifikan. Pengambilan sampel data dilakukan setiap tujuh hari berupa kelangsungan hidup (\%) dan laju penurunan biomassa mutlak (g). Parameter fisika kimia air berupa ammonia dan alkalinitas dilakukan setiap tujuh hari, sedangkan suhu, oksigen terlarut (DO), dan $\mathrm{pH}$ dilakukan setiap hari. Hasil penelitian menunjukkan bahwa kelangsungan hidup tidak berbeda nyata antar perlakuan $(\mathrm{P}>0,05)$ sedangkan laju penurunan biomassa mutlak berbeda nyata antar perlakuan $(\mathrm{P}<0,05)$. Berdasarkan hasil penelitian, salinitas $10 \mathrm{~g} / \mathrm{L}, 20 \mathrm{~g} / \mathrm{L}$, dan $30 \mathrm{~g} / \mathrm{L}$ menunjukkan kelangsungan hidup $100 \%$, sedangkan salinitas $0 \mathrm{~g} / \mathrm{L}$ memberikan kelangsungan hidup terendah. Salinitas $10 \mathrm{~g} / \mathrm{L}$ menunjukkan pemakaian energi terendah untuk metabolisme tubuh sehingga memberikan penurunan bobot biomassa terendah dibandingkan dengan perlakuan lainnya. Hasil penelitian menunjukkan salinitas optimum adalah $10 \mathrm{~g} / \mathrm{L}$, dan setelah dihitung menggunakan analisis regresi kuadratik, maka kisaran salinitas optimum adalah 5,00-13,40 g/L.
\end{abstract}




\section{INTRODUCTION}

A stadium of glass eel is the most vulnerable stage, which contributes to the high mortality if compared with stadia of elver and yellow eel (Durif \& Elie, 2008; Okamoto et al., 2009; Okamura et al., 2009a,b; Chow et al., 2010; Clevestam et al., 2011). Its characteristic that migrates in large group from seawater to brackishwater causes the glass eel to be easily caught in large number in the estuary. Until now, technology of appropriate eel breeding has not yet been found that seed for eel culture still largely depends on nature, while its availability in nature highly depends on the season. Moreover, the growth is also very slow. Development of glass eel into yellow eel stadia in nature takes three to nine years, that is when the sex differentiation occurs and reaches the adult stage (silver eel) three to six years later (Aoyama, 2009). Other constraints include the seed that is not uniform in size, high feed conversion and vulnerable to disease. Development of eel culture method is expected to improve the survival and growth which will have impact on the efficiency of utilization of seed from nature. According Affandi et al. (2013) to optimize the usual environmental conditions with added ingredients (e.g: $\mathrm{NaCl}$ and $\mathrm{CaCO}_{3}$ ) into the medium.

Fasting is one of a method that used for measured growth of fish in a shorter period of time. Glass eel in fasting condition shows negative growth response in term of decrease in body weight. Minimum weight loss occurs when eel is placed in media with optimal salinity for life; thus, the growth of eel will be maximal when eel is fed in this condition. Salinity relates to osmoregulation, that is ion exchange between environment and the body. The stability of acidbase regulation in fish body is also maintained due to ion exchange between the fish blood and water with salinity plays role as facilitato. Boeuf and Payan (2001) stated that fish reared in salinity close to ion concentration in blood (isoosmotic) will provide more energy for growth and spend less energy for osmoregulation. Salinity affects secretion of hormone, standard metabolism, appetite and feed conversion. Moreover, Boeuf and Payan (2001) described that hypoosmotic condition due to high salinity can increase the secretion of growth hormone, appetite, and aggressive behavior that leads to cannibalism.

Salinity is a determinant factor for growth of fishes, including eel (Nordlie, 2009; O'Neill et al., 2011; Perez-Robles et al., 2012; Fazio et al., 2013). Several studies have shown the role of salinity on survival and growth of glass eel. Sutrisno (2008) suggested that salinity of 5 $\mathrm{mg} / \mathrm{L}$ was the best salinity for eel seed Anguilla bicolor with survival rate of $100 \%$ and specific growth rate of $2.33 \%$. Edeline et al. (2005) said that compared to freshwater, salinity of $34 \mathrm{~g} / \mathrm{L}$ and temperature of $18{ }^{\circ} \mathrm{C}$ resulted in the highest growth of glass eel A. anguilla. Lamson et al. (2009) stated that eel A. rostrata increased 2.2 times of length and 5.3 times of weight at salinity $>28 \mathrm{~g} / \mathrm{L}$ compared to freshwater. Furthermore, Kearney et al. (2008) said that salinity of 17.5 $\mathrm{g} / \mathrm{L}$ and temperature of $17.5{ }^{\circ} \mathrm{C}$ produced the highest survival on glass eel $A$. australis and A. dieffenbachia compared to salinity of $35 \mathrm{~g} / \mathrm{L}$ and $0 \mathrm{~g} / \mathrm{L}$. Based on those former study result, it can be concluded that glass eel from each eel species has different salinity preferences, so it must be finding the optimum range of salinity that improve the survival rate and the growth rate of glass eel A. bicolor bicolor. Based on this finding, research to find the optimum salinity range for the survival and growth of glass eel A. bicolor bicolor is required to improve the efficient use of eel seed from nature. The purpose of this study was to determine the optimum salinity range which can improve the survival and growth of g glass eel $A$. bicolor bicolor.

\section{MATERIAL AND METHODS}

\section{Fish treatment preparation}

Glass eels A. bicolor bicolor used in this research were collected from estuary of Cimandiri, Pelabuhan Ratu, Sukabumi, West Java with $0.12-0.20 \mathrm{~g}$ of weight. Glass eels were transported from the fishing area and placed in water with salinity of $10 \mathrm{~g} / \mathrm{L}$. After being transported, glass eels were adapted to salinity of $10 \mathrm{~g} / \mathrm{L}$ for four days before adapted to treatment salinity. Adaptation according to treatment salinity was done gradually by changing the salinity of $2 \mathrm{~g} / \mathrm{L}$ for every $6 \mathrm{~h}$. After reaching the highest $(30 \mathrm{~g} / \mathrm{L})$ and the lowest $(0 \mathrm{~g} / \mathrm{L})$ salinity, glass eels were stocked into each experimental unit according to the treatment given. Water stock of salinity makes with added sea water into fresh water.

\section{Treatment design}

This study used a completely randomized design (CRD) with four treatments namely (A) salinity of $0 \mathrm{~g} / \mathrm{L}$, (B) salinity of $10 \mathrm{~g} / \mathrm{L}$, (C) 
salinity of $20 \mathrm{~g} / \mathrm{L}$, and (D) salinity of $30 \mathrm{~g} / \mathrm{L}$ with three replications of each.

\section{Fish maintenance}

Glass eels were maintained for 14 days and were not given feed (fasted), which aims to obtain changes in fish weight that is maintained in the short term. Aquarium of $60 \times 30 \times 30 \mathrm{~cm}^{3}$ with 30 Liters of volume was used. Stocking density used was $2 \mathrm{~g} / \mathrm{L}$. Full aeration was applied on each experimental unit and water changes was $20 \%$ every day.

\section{Parameters measured}

Parameters measured at the start and the end of maintenance included survival rate and physiology responses (rate of decline in absolute biomass (RDAB), calcium of the body $(\mathrm{CaT})$, protein use during fasting (PU), energy use during fasting (EU), oxygen consumption rate (OC), osmotic gradient (GO). Physical and chemical parameters included temperature, dissolved oxygen, and $\mathrm{pH}$ which were measured daily, while ammonia and alkalinity were measured every seven days.

\section{Survival rate (SR)}

Survival rate (SR) was calculated based on:

$$
\mathrm{SR}=\mathrm{Nt} / \mathrm{No} \times 100
$$

Note:

$\mathrm{SR}=$ survival $(\%)$

$\mathrm{Nt}=$ the number of the alive fish at the final observation (individuals)

No $=$ the number of the alive fish at the initial observation (individuals)

Rate of decline in absolute biomass (RDAB

Rate of decline in absolute biomass (RDAB) which was calculated based on the following equation:

$$
\mathrm{RDBA}=\mathrm{Bt}-\mathrm{Bo} / \mathrm{t}
$$

Note:

$\mathrm{RDAB}=$ rate of decline in absolute biomass $(\mathrm{g} /$ day)

$\mathrm{B}=$ average biomass of fish at time $\mathrm{t}(\mathrm{g})$

Bo $=$ average biomass of fish at initial time $(\mathrm{g})$

$\mathrm{t} \quad=$ time of sampling (day)

Calcium of the body (CaT)

Calcium of the body $(\mathrm{CaT})(\mathrm{mg} / \mathrm{Kg})$ based on SNI 06-6989 12-2005, using atomic absorption spectrophotometer (AAS) method:

$$
\mathrm{CaT}=((\mathrm{a}-\mathrm{b}) \times \mathrm{V} \times \mathrm{DF} \times 1000) / \mathrm{w}
$$

Note:

$\mathrm{CaT}=$ calcium of the body $(\mathrm{mg} / \mathrm{Kg})$

a $\quad=$ concentration of sample solution $(\mathrm{mg} / \mathrm{L})$

$\mathrm{b}=$ concentration of blanko solution $(\mathrm{mg} / \mathrm{L})$

$\mathrm{V}=$ volume excract

$\mathrm{DF}=$ dilution factor

$\mathrm{W} \quad=$ weight of sample $(\mathrm{g})$

Protein use during fasting (PU)

Protein use during fasting (PU), calculated using equation as follows:

$$
\mathrm{PU}=(\mathrm{Pbo}-\mathrm{Pbt}) / \mathrm{Pbo} \times 100
$$

Note:

$\mathrm{PU}=$ use of body protein during fasting (\%)

$\mathrm{Pbo}=$ total of initial body protein $(\mathrm{g})$

$\mathrm{Pbt}=$ total of final body protein $(\mathrm{g})$

Energy use during fasting (EU)

Energy use during fasting (EU), calculated using equation below:

$$
\mathrm{EU}=(\mathrm{Ebo}-\mathrm{Ebt}) / \mathrm{Ebo} \times 100
$$

Note:

$\mathrm{EU}=$ use of body's energy during fasting (\%)

$\mathrm{Eb}_{\mathrm{o}}=$ total of initial body's energy (kcal)

$\mathrm{Eb}_{\mathrm{t}}=$ total of final body's energy (kcal)

\section{Oxygen consumption rate (OC)}

Oxygen consumption rate (OC) on standard metabolism which was calculated with:

Note:

$$
\mathrm{OC}=\mathrm{V} \times(\mathrm{DOo}-\mathrm{DOt}) /(\mathrm{w} \times \mathrm{t})
$$

$\mathrm{OC}=$ oxygen consumption rate $\left(\mathrm{mg} \mathrm{O}_{2} / \mathrm{g} /\right.$ hour $)$

$\mathrm{V} \quad=$ volume of water in culture tank $(\mathrm{L})$

$\mathrm{W}=$ weight of sample $(\mathrm{g})$

DOo $=$ concentration of dissolved oxygen at initial observation $(\mathrm{mg} / \mathrm{L})$

DOt $=$ concentration of dissolved oxygen at time $\mathrm{t}(\mathrm{mg} / \mathrm{L})$

$\mathrm{w} \quad=$ weight of experimental fish $(\mathrm{g})$

$\mathrm{t}=$ observation period (hour)

Osmotic gradient $(G O)$

Osmotic load is in the form of osmotic gradient (GO) which was determined by calculating the difference between osmotic pressure of the media 
Table 1. Survival rate (SR), specific growth rate (SGR) and feed conversion ratio (FCR)

\begin{tabular}{lcccc}
\hline \multirow{2}{*}{ Parameter } & \multicolumn{4}{c}{ Treatment $(\mathrm{g} / \mathrm{L})$} \\
\cline { 2 - 5 } & $0(\mathrm{~A})$ & $10(\mathrm{~B})$ & $20(\mathrm{C})$ & $30(\mathrm{D})$ \\
\hline Survival rate $(\%)$ & $99.43 \pm 0.00 \mathrm{a}$ & $100 \pm 0.00 \mathrm{a}$ & $100 \pm 0.00 \mathrm{a}$ & $100 \pm 0.00 \mathrm{a}$ \\
Rate of decline in absolute & $-2.91 \pm 0.026 \mathrm{a}$ & $-2.79 \pm 0.040 \mathrm{~b}$ & $-2.89 \pm 0.020 \mathrm{a}$ & $-2.95 \pm 0.051 \mathrm{a}$ \\
biomass (g/day) & $70.69 \pm 3.49 \mathrm{~b}$ & $62.78 \pm 0.71 \mathrm{a}$ & $70.00 \pm 0.85 \mathrm{~b}$ & $72.50 \pm 0.79 \mathrm{~b}$ \\
Use of body protein $(\%)$ & $68.17 \pm 2.39 \mathrm{~b}$ & $62.13 \pm 0.10 \mathrm{a}$ & $69.39 \pm 0.42 \mathrm{~b}$ & $70.38 \pm 0.07 \mathrm{~b}$ \\
Use of body energy $(\%)$ & $0.071 \pm 0.0007 \mathrm{a}$ & $0.069 \pm 0.0014 \mathrm{a}$ & $0.085 \pm 0.0007 \mathrm{~b}$ & $0.089 \pm 0.0007 \mathrm{c}$ \\
Osmotic gradient $(\mathrm{mOsm} / \mathrm{L})$ & $0.428 \pm 0.0021 \mathrm{~d}$ & $0.120 \pm 0.0049 \mathrm{a}$ & $0.277 \pm 0.0124 \mathrm{~b}$ & $0.309 \pm 0.0047 \mathrm{c}$ \\
Oxygen consumption $(\mathrm{mgO} / \mathrm{hour} / \mathrm{g})$ & $0.482 \pm 0.005 \mathrm{c}$ & $0.564 \pm 0.001 \mathrm{~d}$ & $0.226 \pm 0.006 \mathrm{a}$ & $0.338 \pm 0.005 \mathrm{~b}$ \\
\hline
\end{tabular}

Note: Different letter in the same row showed the significant different between the treatment $(\mathrm{P}<0.05)$.

and osmotic pressure of fish body fluids. The equation used is:

$$
\mathrm{OG}=[\mathrm{ODI}-\mathrm{OM}]
$$

Description:

$\mathrm{OG}=$ osmotic gradient $\left(\mathrm{mOsm} / \mathrm{L} \mathrm{H}_{2} \mathrm{O}\right)$

ODI = osmolarity of fish body fluids $(\mathrm{mOsm} / \mathrm{L}$ $\left.\mathrm{H}_{2} \mathrm{O}\right)$

$\mathrm{OM}=$ osmolarity of the media $\left(\mathrm{mOsm} / \mathrm{L} \mathrm{H}_{2} \mathrm{O}\right)$

\section{Physical and chemical water parameters}

Physical and chemical water parameters included temperature which was measured using thermometer, $\mathrm{pH}$ was measured using $\mathrm{pH}$-meter, dissolved oxygen was measured using DO-meter, $\mathrm{NH}_{3}$ was measured using spectrophotometer, and alkalinity was calculated using titration method (UNESCO/WHO/UNEP, 1996).

\section{Data analysis}

Data obtained were analyzed using Microsoft Excel 2007 and SPSS ver. 21.1 on a $95 \%$ confidence interval. If significant difference was found, further test of Duncan was performed. Water quality data were analyzed descriptively and presented in table.

\section{RESULTS AND DISCUSSION}

\section{Results}

Data on survival, rate of decline in absolute biomass, protein use, energy use, calcium of the body, osmotic gradient, and oxygen consumption rate of glass eel in each treatment are presented in Table 1. Result of statistical analysis showed that survival was not significantly different
$(\mathrm{P}>0.05)$ between treatments, while the rate of decline in absolute biomass was significantly different $(\mathrm{P}<0.05)$ between treatments.

The result showed that the lowest osmotic gradient was obtained at salinity of $10 \mathrm{~g} / \mathrm{L}$ because closest the iso-osmotic conditions. Thus, affected the level of oxygen consumption concerning the low protein use and energy use. Further, this led to the decline rate in absolute biomass at the lowest salinity of $10 \mathrm{~g} / \mathrm{L}$. So are the ability to store the highest calcium level of the body was found at salinity of $10 \mathrm{~g} / \mathrm{L}$.

Quadratic regression analysis on the relationship between salinity and several growth parameters, namely rate of decline in absolute biomass, protein use, energy use, osmotic gradient, and oxygen consumption are presented in Table 2.

Based on the quadratic regression analysis, closest of a relationships is indicated by the value of $r^{2}$. The greater the value of $r^{2}$ the closer the causal relationship. The highest value of $\mathrm{r}^{2}$ was found in RDAB and OG; thus, it was concluded that the optimum salinity affected the survival and growth of eel seed A. bicolor bicolor ranged between 5.00-13.40 g/L.

Physical and chemical water parameters (temperature, $\mathrm{pH}, \mathrm{DO}$, alkalinity, and $\mathrm{NH}_{3}$ ) are presented in Table 3. Physical and chemical parameter of water in this research was still within the tolerable limit for the survival and growth of glass eel A. bicolor bicolor.

However, despite the physical and chemical water parameter of eel maintenance media was still within the suitability limit, there was increase in the value of $\mathrm{pH}$, alkalinity, and $\mathrm{NH}_{3}$ during the research along with the increase in the value of salinity. 


\section{Discussion}

The range of physical and chemical value of water parameter shown in Table 3 including temperature, $\mathrm{DO}, \mathrm{pH}, \mathrm{NH}_{3}$ and alkalinity in each treatment during maintenance was still in the range of tolerance for the survival and growth of eel seed. This finding is in accordance with the opinion of Ritonga (2014), Herianti (2005), and Wahyudi et al. (2015). Suitability of physical and chemical value of water parameter during this research resulted in high survival rate of eel seed, that was $99.43-100 \%$ (Table 1).

Different salinity in cultivation media led to different value of osmotic gradient. In teleosts, the plasma isosmotic was found in the water salinity of $12 \mathrm{~g} / \mathrm{L}$ (Boeuf \& Payan, 2001; Tsuzuki et al., 2007; Herrera et al., 2009; Nordlie, 2009). Teleost fish, including eel are able to maintain the ionic and osmotic homeostasis by using osmoregulatory mechanisms, which are energy demanding processes (Tseng \& Hwang, 2008). Optimum salinity is a condition close to isosmotic thus produces the lowest value of osmotic gradient. In accordance with Lisboa et al. (2015) was stated that growth would be maximized when fish is reared in water of salinity near the isosmotic conditions. Otherwise, value of osmotic gradient is higher than the optimum salinity in hyperosmotic or hypoosmotic condition. Increase in osmotic gradient leads to increase in osmotic load thus affecting the rate of oxygen consumption. When the body cannot tolerate changes in salinity, osmotic load within the body will increase and later fish will not be able to adapt and die. When salinity level is close to isosmotic condition, osmotic load will be low so that catabolism of protein, fat and carbohydrates will also be low, resulting in less energy consumption for osmoregulation so that growth will increased.

Salinity also affects calcium content in the body of glass eel. According to Kucuk (2013), plasma osmolality and ionic $\left(\mathrm{Na}^{+}, \mathrm{Cl}^{-}, \mathrm{K}^{+}\right.$, and $\mathrm{Ca}^{2+}$ ) concentrations slightly increased with salinity. Next, Kucuk et al. (2013); Scabra et al. (2016), was stated that salinity is described as the sum of all ions in water, likes sodium, chloride, calcium, magnesium, potassium, bicarbonate, and sulfate ions. In treatment of $10 \mathrm{~g} / \mathrm{L}$ salinity which is close to optimum salinity, eel seeds were able to maintain the highest level of calcium in the body compared to other treatments (Table 1). Research results in Table 1 indicated that the lowest rate of decline in absolute biomass was found in treatment $\mathrm{B}(10 \mathrm{~g} / \mathrm{L})$ due to the reason that salinity of $10 \mathrm{~g} / \mathrm{L}$ was closer to the ion concentration in the blood

Table 2. Value of the best growth parameter at optimum salinity

\begin{tabular}{llcc}
\hline \multicolumn{1}{c}{ Parameter } & \multicolumn{1}{c}{ Regression equation } & $\mathrm{r}^{2}$ & Salinity $(\mathrm{g} / \mathrm{L})$ \\
\hline Rate of decline in absolute biomass (g/day) & $\mathrm{y}=-0.0005 \mathrm{x}^{2}+0.0134 \mathrm{x}-2.9142$ & $\mathbf{0 . 8 8 7 7}$ & $\mathbf{1 3 . 4 0}$ \\
Use of body protein (\%) & $\mathrm{y}=0.026 \mathrm{x}^{2}-0.6538 \mathrm{x}+69.695$ & 0.6408 & 12.57 \\
Use of body energy (\%) & $\mathrm{y}=0.0176 \mathrm{x}^{2}-0.3877 \mathrm{x}+67.186$ & 0.5348 & 11.01 \\
Osmotic gradient (mOsm/L) & $\mathrm{y}=0.00002 \mathrm{x}^{2}+0.0002 \mathrm{x}+0.0689$ & $\mathbf{0 . 8 2 6 6}$ & $\mathbf{5 . 0 0}$ \\
Oxygen consumption $\left(\mathrm{mgO}_{2}\right.$ /hour/g) & $\mathrm{y}=0.0009 \mathrm{x}^{2}-0.0275 \mathrm{x}+0.3983$ & 0.6364 & 17.21 \\
\hline
\end{tabular}

Note: Number in bold shows the closer the causal relationships.

Table 3. Value of physical and chemical water parameter of each treatment during maintenance

\begin{tabular}{|c|c|c|c|c|c|}
\hline \multirow{2}{*}{ Parameter } & \multicolumn{4}{|c|}{ Treatment $(\mathrm{g} / \mathrm{L})$} & \multirow{2}{*}{$\begin{array}{c}\text { Suitability of } \\
\text { physical and } \\
\text { chemical of water }\end{array}$} \\
\hline & A (0) & B (10) & C (20) & $\mathrm{D}(30)$ & \\
\hline Temperature $\left({ }^{\circ} \mathrm{C}\right)$ & $28.9-30.5$ & $29.6-30.8$ & $29.1-30.5$ & $30.2-30.6$ & $23-32^{1}$ \\
\hline $\mathrm{DO}(\mathrm{mg} / \mathrm{L})$ & $5.7-6.1$ & $5.4-6.3$ & $5.4-6.6$ & $5.1-5.9$ & $>32$ \\
\hline $\mathrm{pH}$ & $7.18-7.24$ & $8.20-8.34$ & $8.24-8.45$ & $8.45-8.52$ & $6.0-8.0^{1}$ \\
\hline $\begin{array}{l}\text { Alkalinity } \\
\text { (mg/L CaCO3) }\end{array}$ & $67.28-68.77$ & $112.13-119.60$ & $134.55-146.51$ & $179.4-186.88$ & $30-500^{3}$ \\
\hline $\mathrm{NH} 3(\mathrm{mg} / \mathrm{L})$ & $0.0001-0.0040$ & $0.0013-0.0014$ & $0.0015-0.0018$ & $0.0020-0.0022$ & $>0.01 \mathrm{mg} / \mathrm{L}^{3}$ \\
\hline
\end{tabular}

Note: ${ }^{1}$ Ritonga (2014), ${ }^{2}$ Herianti (2005), ${ }^{3}$ Wahyudi et al. (2015). 
(iso-osmotic) that there will be less energy used for osmotic regulation in the body if compared to other treatments. Statistical analysis showed significant difference result between treatment $\mathrm{A}$ and treatment $\mathrm{B}, \mathrm{C}$, and $\mathrm{D}$.

Salinity affects the osmoregulation activity. Boeuf and Payan (2001) stated that changes in salinity may affect the osmotic pressure of body fluids of glass eel so that more energy is used for osmoregulation. Results showed that there was increase in the value of osmotic gradient in salinity of $0 \mathrm{~g} / \mathrm{L}, 20 \mathrm{~g} / \mathrm{L}$, and $30 \mathrm{~g} / \mathrm{L}$. Increase in the value of osmotic gradient affected the growth rate of eel seed which was reflected in the increasing decline in the weight of eel seed (Table 1). It explains that the higher the value of osmotic gradient, the greater the energy used for osmoregulation. The results showed that salinity of $10 \mathrm{~g} / \mathrm{L}$ is close to isosmotic condition so that the use of body's energy for osmoregulation showed the lowest value. This result is confirmed by the lowest value of oxygen consumption compared to other salinity treatments (Table 1). Petersen et al. (2014), stated that eels survived prolonged exposure to 5 and 10 $\mathrm{g} / \mathrm{L}$, although plasma osmolality increased at 10 $\mathrm{g} / \mathrm{L}$

Boeuf and Payan (2001) suggested that salinity also affects the secretion of hormone, standard metabolism, appetite and feed conversion. Treatment of $10 \mathrm{~g} / \mathrm{L}$ resulted in the lowest oxygen consumption rate of eel seeds during 14 days of fasting compared to other salinity treatments. This is in accordance with the opinion of Boeuf and Payan (2001) which stated that fish in a condition close to isotonic has lower metabolic rate than those at hypotonic and hypertonic condition. Hypoosmotic and hyperosmotic conditions cause metabolic activity of glass eel body increases which will affect oxygen consumption, osmoregulation activity, body's energy use, and excretion rate. Glass eels reared in condition close to isosmotic $(10 \mathrm{~g} / \mathrm{L})$ used less energy for metabolism which impacted on lower ammonia excretion (Table 3).

Osmotic gradient value increased with salinity increases. The value osmotic gradient will be lower when it is closer to the isosmotic condition, consequently, oxygen consumption rate, protein use, and energy use by eel seed will also be low during fasting. As a consequence, eel used less energy for metabolism and more energy for growth. Result showed that the value of osmotic gradient, oxygen consumption rate, protein use, and energy use was found to be the lowest in treatment of $10 \mathrm{~g} / \mathrm{L}$ salinity, thus resulted in the lowest rate of decline in absolute biomass.

Decrease in weight reflects the amount of energy spent by glass eel during fasting. The lower the weight loss during fasting indicates the less use of energy for metabolic activity and other biological activities. According to Boeuf and Payan (2001), salinity affects the growth of fish concerning the use of energy for osmoregulation.

Treatment A $(0 \mathrm{~g} / \mathrm{L})$ showed the highest decrease in biomass and the lowest survival. This result was likely due to characteristics of glass eel which prefers brackishwater to freshwater. According to Wilson et al. (2007), glass eels will migrate from spawning area at the sea to the estuary to reach the elver stadia and grow in freshwater habitat until they reach the yellow eel stage. Edeline et al. (2005) also stated that glass eel can survive at acute salinities during migration from seawater into freshwater, yet glass eel will adapt to changes in salinity in the estuary area before reaching freshwater. Salinity treatment of $20 \mathrm{~g} / \mathrm{L}$ and $30 \mathrm{~g} / \mathrm{L}$ put the eel seeds in hyperosmotic conditions which esulted in higher decrease in weight than that in $10 \mathrm{~g} / \mathrm{L}$ salinity. Fazio et al. (2013) stated that stress related to changes in water salinity can induce alterations in metabolic energy production and utilization.

Several studies found that glass eels $A$. rostrata from different habitats (freshwater and brackishwater) have different growth pattern as they are different in term of quantitative genetics (Cote et al., 2009). Glass eel A. Anguilla and A. rostrata reared in seawater showed significantly higher growth compared to those reared in freshwater (Edeline et al., 2005; Lamson et al., 2009).

Result of quadratic regression analysis (Table 2) concerning the relationship between salinity and growth showed causal relationship between salinity and the rate of decline in absolute biomass and also osmotic gradient of glass eel during maintenance. Changes in salinity affected the rate of decline in absolute biomass $\left(\mathrm{r}^{2}=0.8877\right)$ and osmotic gradient $\left(r^{2}=0.8266\right)$. Based on this result, optimum salinity range for the survival and growth of glass eel A. bicolor bicolor was $5.00-13.40 \mathrm{~g} / \mathrm{L}$.

\section{CONCLUSION}

Salinity of $10 \mathrm{~g} / \mathrm{L}$ gave a good conditions for lived and growth of glass eel A. bicolor bicolor. But, the optimum range of salinity to improve 
survival and growth of glass eel A. bicolor bicolor was $5.0-13.4 \mathrm{~g} / \mathrm{L}$. The increase of survival and growth rate of glass eel in culture will be impact to sustainability of it in natural waters.

\section{ACKNOWLEDMENT}

The authors would like to thank to the Directorate General of Higher Education, Ministry of Research and Technology Education and Culture who have funded so that this research can be implemented, and to Directorate General of Reinforcement Improvement and Research (DRPM) Indonesian Ministry of Research and Technology of Higher Education for research grant aid of doctoral dissertation grant on 2017.

\section{REFERENCES}

Affandi R, Budiardi T, Wahju RI, Taurusman AA. 2013. Eel rearing in water recirculation system. Jurnal Ilmu Pertanian Indonesia 18: 55-60.

Aoyama J. 2009. Life history and evolution of migration in catadromous eels (Genus Anguilla). Aqua-BioScience Monographs 2: 1-42.

Boeuf G, Payan P. 2001. How should salinity influence fish growth? Comparative Biochemistry and Physiology Part C: Toxycology and Pharmacology 130: 411-423.

Chow S, Kurogi, Katayama H. 2010. Japanese eel Anguilla japonica do not assimilate nutrition during the oceanic spawning migration: evidence from stable isotope analysis. Marine Ecology Progress Series 402: 233-238.

Clevestam PD, Ogonowski M, Sjcoberg NB, Wickstrcom H. 2011. Too short to spawn? Implications of small body size and swimming distance on successful migration and maturation of the European eel Anguilla anguilla. Journal of Fish Biology 78: 10731089.

Cote CL, Castonguay M, Verreault G, Bernatches L. 2009. Differential effects of origin and salinity rearing conditions on growth of glass eel of the american eel Anguilla rostrata: Implications for stocking programmes. Journal of Fish Biology 74: 1934-1948.

Durif CMF, Elie P. 2008. Predicting downstream migration of silver eels in a large river catchment based on commercial fishery data. Fisheries Management and Ecology 15: 127137.
Edeline E, Dufour S, Elie P. 2005. Role of glass eel salinity preference in the control of habitat selection and growth plasticity in Anguilla anguilla. Marine Ecology Progress Series 304: 191-199.

Fazio F, Marafioti S, Arfuso F, Piccione G, Faggio C. 2013. Influence of different salinity on haematological and biochemical parameters of the widely cultured mullet, Mugil cephalus. Marine and Freshwater Behaviour and Physiology 46: 211-218.

Herianti I. 2005. Environmental engineering to accelerate ovarian development on eel Anguilla bicolor. Oseanologi dan Limnologi Indonesia 37: 25-41.

Herrera M, Vargas-Chacoff L, Hachero I, RuízJarabo I, Rodiles A, Navas JI, Mancera JM. 2009. Osmoregulatory changes in wedge sole Dicologoglossa cuneata Moreau, 1881 after acclimation to different environmental salinities. Aquaculture Research 40: 762-771.

Kearney M, Jeffs A, Lee P. 2008. Effects of salinity and temperature on the growth and survival of New Zealand shortfin, Anguilla australis, and longfin A. dieffenbachia, glass Eel. Aquaculture Research 39: 1769-1777.

Kucuk S, Karul A, Yildirim S, Kutsai G. 2013. Effects of salinity on growth and metabolism in blue tilapia Oreochromis aureus. African Journal of Biotechnology 12: 2715-2721.

Kucuk S. 2013. The effects of salinity on growth of goldfish, Carassius auratus and crucian carp, Carassius carassius. African Journal of Biotechnology 12: 2082-2087.

Lamson HM, Cairns DK, Shiao CJ, Iisuka Y, Tzeng WN. 2009. American eel, Anguilla rostrata, growth in fresh and salt water: implications for conservation and aquaculture. Fisheries Management and Ecology 16: 306314.

Lisboa V, Barcarolli IF, Sampaio LA, Bianchini A. 2015. Effect of salinity on survival, growth and biochemical parameters in juvenile Lebranch mullet Mugil liza (Perciformes: Mugilidae). Neotropical Icthyology 13: 447-452.

Nordlie FG. 2009. Environmental influences on regulation of blood plasma serum components in teleost fish: a review. Reviews in Fish Biology and Fisheries 19: 481-564.

Okamoto T, Kurokawa T, Gen K, Murashita K, Nomura K, Kim SK, Matsubara H, Ohta H, Tanaka H. 2009. Influence of salinity on morphological deformities in cultured larvae of Japanese eel, Anguilla japonica at 
completion of yolk resorption. Aquaculture 293: 113-118.

Okamura A, Yamada Y, Horita T, Horie N, Mikawa N, Utoh T, Tanaka S, Tsukamoto K. 2009a. Rearing eel leptocephali Anguilla japonica Temminck \& Schlegel in a planktonreisel. Aquaculture 40: 509-512.

Okamura A, Yamada Y, Mikawa N, Horie N, Utoh T, Kaneko T, Tanaka S, Tsukamoto K. 2009b. Growth and survival of eel leptocephali Anguilla japonica in low-salinity water. Aquaculture 296: 367-372.

O`Neill B, De Raedemaecker F, McGrath D, Brophy D. 2011. An experimental investigation of salinity effects on growth, development and condition in the European flounder Platichthys flesus L. Journal of Experimental Marine Biology and Ecology 410: 39-44.

Pérez-Robles J, Re AD, Giffard-Mena I, Díaz F. 2012. Interactive effects of salinity on oxygen consumption, ammonium excretion, osmoregulation and $\mathrm{Na}^{+} / \mathrm{K}^{+}$-ATPase expression in the bullseye puffer Sphoeroides annulatus, Jenyns 1842. Aquaculture Research 43: 1372-1383.

Petersen PBM, Hansen K, Houng DTT, Bayley M, Wang T. 2014. Effects of salinity on osmoregulation, growth and survival in asian swamp eel Monopterus albua (Zuiew 1793). Aquaculture Research 45: 427-438.

Ritonga T. 2014. The response of eel fish seed Anguilla bicolor bicolor to the degree of acidity $(\mathrm{pH})$ [Mini Thesis]. Bogor: Institut Pertanian Bogor.
Scabra AR, Budiardi T, Djokosetiyanto D. 2016. Production performance of Indonesian eel Anguilla bicolor bicolor with the addition of calcium carbonate $\left(\mathrm{CaCO}_{3}\right)$ in to the culture media. Jurnal Akuakultur Indonesia 15: 1-7.

Sutrisno. 2008. Determination of water salinity and proper type of natural feed in the maintenance of eel seeds Anguilla bicolor. Jurnal Akuakultur Indonesia 7: 71-77.

Tseng YC, Hwang PP. 2008. Some insights into energy metabolism for osmoregulation in fish. Comparative Biochemistry and Physiology, Part C 148: 419-429.

Tsuzuki MY, Sugai JK, Maciel JC, Francisco CJ, Cerqueira VR. 2007. Survival, growth and digestive enzyme activity of juveniles of the fat snook Centropomus parallelus reared at different salinities. Aquaculture 271:319-325.

UNESCO/WHO/UNEP. 1996. Water Quality Assessments - A Guide to Use of Biota, Sediments and Water in Environmental Monitoring - Second Edition. F \& FN Spon: London.

Wahyudi H, Affandi R, Hariyadi S. 2015. Response of eel seed Anguilla bicolor bicolor to ammonia $\left(\mathrm{NH}_{3}\right)$ on the maintenance media [Mini Thesis]. Bogor: Institut Pertanian Bogor.

Wilson JM, Leitio A, Goncalves AF, Ferreira C, Santos PR, Fonseca AV, da Silva JM, Antones JC, Pereira C, Wilson, Coimbra J. 2007. Modulation of brancial ion transport protein expression by salinity in glass eel Anguilla L. Marine biology 151: 1633-1645. 